\title{
Characterization of bacteriocin and chitinase producing bacterial isolates with broad-spectrum antimicrobial activities
}

\author{
Muhammad Yasir $^{1} \cdot$ Basit Zeshan ${ }^{1} \cdot$ Nur Hardy A. Daud ${ }^{2} \cdot$ Izzah Shahid $^{1} \cdot$ Hafza Khalid $^{1}$
}

Received: 2 March 2021 / Accepted: 15 July 2021

Published online: 28 July 2021

(c) The Author(s) 2021 OPEN

\begin{abstract}
There is a need for more efficient and eco-friendly approaches to overcome increasing microbial infections. Bacteriocins and chitinases from Bacillus spp. can be powerful alternatives to conventional antibiotics and antifungal drugs, respectively. The purpose of this study was to assess the inhibitory potential of bacteriocins and chitinase enzymes against multiple resistant bacterial and fungal pathogens. Bacterial isolates were selected by growth on minimal salts medium and after that were morphologically and biochemically characterized. The physiochemical characterization of bacteriocins was carried out. The inhibitory potential of bacteriocins towards six pathogenic bacteria was determined by the well diffusion assay while chitinase activity towards three fungal strains was determined by the dual plate culture assay. Two bacterial strains $\left(W_{2} \mathrm{P}_{1}\right.$ and $\mathrm{WRE}_{4} \mathrm{P}_{2}$ ), out of nine showed inhibition of $K$. pneumonia, P. aeruginosa, E. coli and MRSA while WW $\mathrm{P}_{4}$ was positive against S. typhimurium and $E$. coli and $W R E_{10} P_{2}$ against $P$. aeruginosa, $S$. pneumoniae. Two bacterial isolates $\left(W_{3} \mathrm{P}_{1}\right.$ and $\left.W R E_{10} \mathrm{P}_{2}\right)$ were chosen for further study on the basis of their antifungal activities. Of these, $W W_{3} P_{1}$ isolate was more effective against $A$. fumigatus as well as A. niger. The proteinaceous nature of the bacteriocins was confirmed by treatment of the crude extract with proteinase $\mathrm{K}$. It was found that the inhibitory activity of strain $W W_{3} \mathrm{P}_{1}$ against $E$. coli was highest at $20^{\circ} \mathrm{C}$, and against $S$. pneumoniae it was at $20^{\circ} \mathrm{C}$ and pH 10 after treatment with EDTA. Inhibition by strain the WRE ${ }_{10} \mathrm{P}_{2}$ against $P$. aeruginosa was highest at $20^{\circ} \mathrm{C}$ and $\mathrm{pH} 14$. It was found that EDTA increased the inhibitory activity of strain WW $\mathrm{P}_{1}$ against $P$. aeruginosa, $K$. pneumoniae and $E$. coli by $2 \pm 0.235,3.5 \pm 0.288,2.5 \pm 1.040$ times, respectively, of strain $\mathrm{WRE}_{4} \mathrm{P}_{2}$ against $P$. aeruginos $a$ and $E$. coli by $2.5 \pm 0.763,2.7 \pm 0.5$ times, respectively, and of strain $\mathrm{WRE}_{10} \mathrm{P}_{2}$ against $S$. pneumoniae by $3 \pm 0.6236$ times. The isolates have promising inhibitory activity, which should be further analyzed for the commercial production of antimicrobials.
\end{abstract}

\section{Article highlights}

1. The current study aimed to isolate the microbiome from wheat plant (Triticum aestivum L.), to screen for bacteriocin production and to assess its antimicrobial activity against human pathogens.

2. Forty-one phenotypically different bacterial colonies were subjected to bacteriocin purification from which 25 colonies showed positive reactions.
3. These 25 bacterial isolates were screened against six different human bacterial pathogens using the well diffusion method to check the antimicrobial activity. Out of nine bacterial isolates, WW3P1 and WRE10P2 were able to degrade the chitin and utilize it as their sole energy source. Strain WRE4P2 exhibited partial inactivation in its activity against MRSA after treatment with proteinase $\mathrm{K}$.

Supplementary Information The online version contains supplementary material available at https://doi.org/10.1007/s42452-02104740-z.

Basit Zeshan, dr.basitzeshan@ucp.edu.pk | 1 Department of Microbiology, Faculty of Life Sciences, University of Central Punjab, Lahore 54000, Pakistan. ${ }^{2}$ Faculty of Sustainable Agriculture, Universiti Malaysia Sabah, Sandakan Campus, Locked Bag No.3, 90509 Sandakan, Sabah, Malaysia. 
Keywords Bacteriocins · Chitinase $\cdot$ Bacillus $\cdot$ Antibacterial $\cdot$ Aspergillus $\cdot$ Antifungal

\section{Introduction}

The genus Bacillus represents a large group of gram-positive bacteria that belongs to the phylum Firmicutes. They are rod-shaped with aerobic or facultative anaerobic metabolic characteristics [1]. They inhabit a large variety of ecological niches: soil, water, air, the surfaces and rhizosphere of plants, the gastrointestinal tract of animals and many extreme environments. A key feature of the Bacillus species is its diverse secondary metabolism and its ability to produce a wide variety of structurally different antagonistic substances. Strains of Bacillus subtilis have approximately $4-5 \%$ of their whole genomes dedicated to synthesis of secondary metabolites, with the capability of producing more than two dozen structurally diverse antimicrobial compounds [2].

The antimicrobial compounds produced by bacteria are of two main categories; the antibiotics and the bacteriocins. Antibiotics are metabolic end products while bacteriocins are proteinaceous substances synthesized by ribosomes [3]. The main difference between antibiotics and bacteriocins is that antibiotics have broad spectrum activity and can inhibit the growth of bacteria across genera even with restricted activity which does not affect the closely related bacterial strains, while bacteriocins commonly show activity against closely related species or the strains of same species [4].

The microbiome residing in plant rhizosphere and biotopes helps them in the struggle for nutrients and the fight against pathogens. One of the methods of fighting pathogens is by the production of bacteriocins. Bacteriocins are synthesized by ribosomes as precursors and undergo post-translational modification for extracellular secretion $[5,6]$. Bacteriocins have been reported from both, gram-positive and gram-negative bacteria and are further classified into sub-classes on the basis of heterogeneity, variation in molecular weight, biochemical characteristics and, mode of production and action [7]. They act either as bacteriostatic or bactericidal antimicrobial peptides (AMPs) and possess narrow-spectrum or broadspectrum activities against different pathogens. Bacteriocins from gram-positive bacteria, e.g. Bacillus, can be categorized into four major classes, namely, Class I, II, III, and IV. AMPs have a significant role in the pharmaceutical and food industries [8].

As chitin is the second most abundant biopolymer in nature, it gets recycled this way [7]. There are three glycosyl hydrolase $(\mathrm{GH})$ families of chitinolytic enzymes numbered 18, 19, and 20. Only families 18 and 19 glycosidases are considered as chitinases because they catalyze chitin polymers and have been demonstrated to suppress several fungal phytopathogens, such as certain pathogenic fungi that are responsible for infections which damage body tissues in immunocompromised individuals [9]. For example, Aspergillus causes a serious pulmonary infection in cancer patients called aspergillosis $[10,11]$. The Bacillus spp. has the ability to divide rapidly and display resistance to high temperature and other unfavorable environmental conditions such as salinity. Consequently, their bacteriocins and chitinases have been widely explored for their role as the agents of disease management [12].

In this study, Bacillus spp. from wheat (Triticum aestivum L.) rhizosphere were isolated and screened for their ability to produce bacteriocins and chitinases. Antimicrobial activities of the bacterial isolates were determined against pathogenic bacteria and fungi. Following antimicrobial assays, the isolates were subjected to physicochemical characterization for their potential use as antimicrobial agents.

\section{Materials and methods}

\subsection{Sample collection}

Three wheat plant (Triticum aestivum) samples were taken from a farm field in the Lahore district (Mohlanwal; $31.3695^{\circ} \mathrm{N}, 74.1768^{\circ} \mathrm{E}$ ) following aseptic techniques and were carefully transferred to the Microbiology Research Laboratory. The samples were divided into two parts, i.e., phyllosphere and rhizosphere, and were kept in sterile polyethylene packets at $4^{\circ} \mathrm{C}$.

\subsection{Isolation of bacteria from plant samples}

For the isolation of phyllosphere bacterial isolates, $3 \mathrm{~g}$ of phyllosphere leaves were thoroughly washed and immersed in sterile distilled water for $10 \mathrm{~min}$. The leaves were then crushed in a sterile pestle and mortar using $10 \mathrm{~mL}$ of autoclaved $0.85 \%$ normal saline solution (NSS). Endophytic bacteria were also isolated from the roots of the wheat plant. Three grams of root were thoroughly rinsed in sterile distilled water and re-suspended in $10 \mathrm{~mL}$ of NSS. The sample was completely crushed to a refined slurry in a sterile pestle and mortar, and stored aseptically. Rhizosphere bacterial isolations were performed from $1 \mathrm{~g}$ of root-adhered soil suspended in $10 \mathrm{~mL}$ of NSS. The 
soil sample was incubated at $37^{\circ} \mathrm{C}$ for $24 \mathrm{~h}$ in a shaking incubator.

Serial dilutions from phyllosphere, rhizosphere, and plant roots were prepared up to $10^{-5}$ [13]. Following serial dilutions, $100 \mu \mathrm{L}$ of each dilution were taken and individually spread on Lauria Bertani (LB) and nutrient agar (NA) plates. The plates were sealed and incubated at $37{ }^{\circ} \mathrm{C}$ for $24 \mathrm{~h}$. Chitinolytic bacteria were isolated by inoculating $1 \mathrm{~mL}$ of previously enriched culture into mineral salt medium (MSM) and keeping it in the shaking incubator for 7 days. For the preparation of colloidal chitin, the protocol of Rodriguez et al. [14] was followed with slight modifications. According to this method $20 \mathrm{~g}$ of chitin from crab shell was dissolved in cold concentrated $\mathrm{HCl}$ and placed in refrigerator for $24 \mathrm{~h}$. The mixture was filtered through glass wool into a flask containing $2 \mathrm{~L}$ of chilled ethanol with continuous stirring. The chitin suspension was then centrifuged at 10,000 rpm for $20 \mathrm{~min}$. The chitin pellet was washed several times with distilled water until the $\mathrm{pH}$ was neutral.

\subsubsection{Code designation to bacterial isolates from plant samples}

The bacterial strains were given codes according to the following criteria:

$\mathrm{P}=$ plant, $\mathrm{P} 1=$ Plant \# 1, P2 = Plant \# 2, P3 = Plant \# 3, $\mathrm{W}=$ Wheat, $\mathrm{W} 1=$ after 1 st wash, $\mathrm{W} 2=$ after 2 nd wash. W3 = after 3rd wash, W4 = after 4th wash, $\mathrm{R}=$ rhizosphere.

\subsection{Assessment of the antimicrobial activity of isolates}

\subsubsection{Antibacterial activity}

Isolates were screened for their antibacterial activity against six human pathogenic bacteria (K. pneumoniae, $P$. aeruginosa, MRSA (Methicillin resistant Staphylococcus aureus), S. typhimurium, E. coli, and S. pneumoniae) through agar well diffusion assay [15]. Identified bacterial pathogens were obtained from microbial culture collection of University of Central Punjab. All bacterial isolates and pathogens were cultivated/grown in $10 \mathrm{~mL}$ LB broth and kept overnight in shaking incubator at $37{ }^{\circ} \mathrm{C}$. Following incubation, $100 \mu \mathrm{L}$ of each pathogen bacterial culture was evenly spread on separate LB agar plates using a sterile spreader. Three $6 \mathrm{~mm}$ wells were dug on the LB agar plates using sterile blue tips and $25 \mu \mathrm{L}$ of each test bacterial culture $\left(1 \times 10^{7}\right.$ cells $\left./ \mathrm{mL}\right)$ was filled in each well. The plates were sealed with parafilm and placed in a static incubator at $37^{\circ} \mathrm{C}$ for $24 \mathrm{~h}$. They were observed for clear zones of growth inhibition around the agar wells.

\subsubsection{Detection of Antifungal activity}

Antifungal activity of bacterial isolates was tested using the dual-culture method. The medium used as a source of nutrition for bacteria and fungi was a combination of $50 \%$ potato dextrose agar (PDA) and 50\% NA as described by Yanti et al. [5]. Three Aspergillus strains, namely, A. niger, $A$. fumigatus and, $A$. nidulans were obtained from the Chughtai Lahore laboratory. Pure fungal cultures previously incubated for 5-7 days at $30{ }^{\circ} \mathrm{C}$ were used to inoculate test plates. A fungal plug of $5 \mathrm{~mm}^{2}$ was cut from the stock plate and placed at one end of the prepared test plates. A single bacterial colony of the test isolate was picked from freshly grown bacterial culture and streaked as a straight line on the other end of agar plate $(2 \mathrm{~cm}$ apart). The plates were wrapped with parafilm tape and placed in an incubator at $32{ }^{\circ} \mathrm{C}$ for 5 days to observe fungal inhibition.

\subsection{Identification of bacterial isolates}

Those isolates which showed considerable antimicrobial activity were selected for biochemical identification using the QTS-24 bacterial identification kits (DESTO Laboratories, Karachi, Pakistan) and proceeded for standard biochemical assays to characterized Gram negative and Gram positive bacteria [16-18].

\subsection{Cytochrome oxidase test}

Individual colonies of bacterial isolates were rubbed on CO strips using the QTS-24 kit. Change in the color of the CO strip from white to blue was considered as positive.

\subsection{Partial purification of bacteriocins}

Bacterial isolates showing antimicrobial activity were subjected to bacteriocin purification using ammonium sulphate precipitation, as described by Pingitore et al. [19]. For bacteriocin production, bacterial isolates were inoculated separately in $100 \mathrm{~mL}$ of LB broth at standard culture conditions, for $24 \mathrm{~h}$. After incubation, cells were removed by centrifugation at $10,000 \mathrm{rpm}$ for $10 \mathrm{~min}$ and the cellfree supernatant (CFS) was taken, followed by filtration through a syringe filter, with a pore size of $0.45 \mu \mathrm{m}$. The filtered supernatant was saturated by adding ammonium sulfate (40-50\%) and allowed to settle overnight at $4{ }^{\circ} \mathrm{C}$. The protein precipitates were recovered the following day by centrifugation at $10,000 \mathrm{rpm}$ for $12 \mathrm{~min}$ and redissolved in $500 \mu \mathrm{L}$ of $5 \mathrm{X}$ phosphate buffer saline (PBS). The 
protein pellet with PBS was considered partially purified bacteriocin and assayed for activity.

\subsection{Effect of proteinase $\mathrm{K}$ on bacteriocin activity}

The proteinase K enzyme was used to confirm the proteinaceous nature of partially purified bacteriocins. Isolated bacteriocins were treated with $1 \mathrm{mg} / \mathrm{mL}$ of proteinase $\mathrm{K}$ for $2 \mathrm{~h}$ at $37^{\circ} \mathrm{C}$ and subjected to antibacterial assay against bacterial pathogens [20].

\subsection{Physicochemical characteristics of bacteriocins}

In order to examine how temperature affects the activity of bacteriocins, they were previously incubated at five different temperatures i.e., $20,40,60,80$ and $100^{\circ} \mathrm{C}$. Temperature-treated bacteriocins were used for antibacterial assay and the inhibition zones were measured.

The effect of $\mathrm{pH}$ on the activity of bacteriocins was tested according to the protocol of Mandal et al. [21]. Bacteriocins isolated from $100 \mathrm{~mL}$ of each bacterial culture were adjusted to different $\mathrm{pH}(2,4,6,8,10,12$ and 14) with $1 \mathrm{M} \mathrm{HCl}$ and $1 \mathrm{M} \mathrm{NaOH}$ respectively, and incubated for $2 \mathrm{~h}$ at room temperature. The antibacterial activity of each bacteriocin aliquot was then recorded.

EDTA and SDS were used to analyze the effect of surfactants on the activity of bacteriocins. Partially purified bacteriocins were treated with $1 \%(\mathrm{v} / \mathrm{v})$ of the surfactants and incubated at room temperature for $2 \mathrm{~h}$, following the determination of antibacterial activity against pathogens [3]. All tests were performed in triplicate and the mean was calculated. Untreated, partially purified bacteriocins of each bacterial isolate were used as controls.

\section{Results}

\subsection{Isolation and selection of bacteria}

Forty-one phenotypically different bacterial colonies, which were isolated from rhizosphere, roots, and phyllosphere samples, were subjected to purification, purified bacteriocins showed positive activity for 25 bacterial isolates. Of these 25 isolates, 9 showed inhibition of pathogens, and were selected for detailed characterization. Partially purified bacteriocins from the isolates were analyzed for physicochemical analysis by treating them with proteinase $\mathrm{K}$, surfactants and incubation at different $\mathrm{pH}$ and temperatures. All of these 25 isolates were screened against 6 human bacterial pathogens by agar well-diffusion assay.

Out of 9 bacterial isolates, 2, namely $W W_{3} P_{1}$ and $W R E_{10} P_{2}$, were able to degrade chitin and utilized chitin as the sole energy source.

\subsection{Morphological and biochemical characteristics of bacterial isolates}

\subsubsection{Morphology and biochemical tests}

Figures 1 and 2 illustrates morphologically distinct purified bacterial isolates. Biochemical characterization of bacteria was based on the QTS-24 identification kits as shown in Fig. 2. Table 1 gives an outline for results of all biochemical tests and preliminary bacterial identification.
Fig. 1 Growth of bacterial isolates on MSM Agar plates






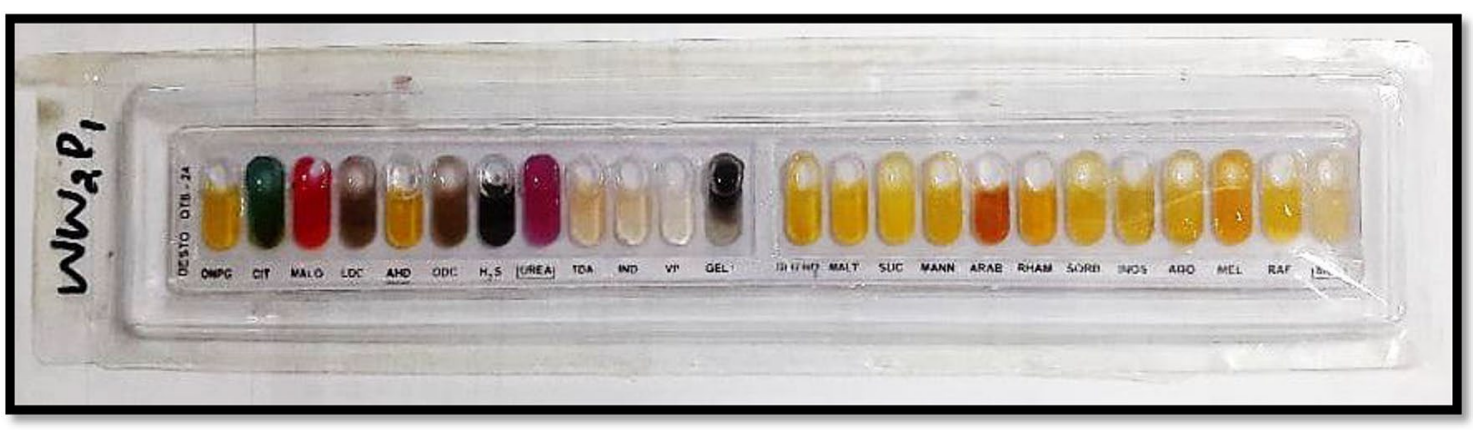

Fig. 2 Biochemical identification of bacterial strain $W_{2} P_{1}$ by using QTS-24 identification kit

\subsubsection{Cytochrome oxidase test}

All bacterial isolates shown negative results for cytochrome oxidase production when rubbed on $\mathrm{CO}$ test strips provided with QTS-24 bacterial identification kits.

\subsection{Partial purification of bacteriocins and evaluation of antibacterial activity}

The antibacterial activity of partially purified bacteriocins from ammonium sulfate precipitation of the 25 isolates was assessed against six different human bacterial pathogens. Nine isolates showed positive results while the remaining 16 did not show any antibacterial activity towards bacterial pathogens. Of the 9 isolates, $W W_{2} P_{1}$ and $\mathrm{WRE}_{4} \mathrm{P}_{2}$, inhibited three pathogens: $\mathrm{WW}_{2} \mathrm{P}_{1}$ suppressed $K$. pneumoniae, $P$. aeruginosa and $E$. coli while $\mathrm{WRE}_{4} \mathrm{P}_{2}$ was showed considerable inhibition of $P$. aeruginosa, MRSA and $E$. coli. Isolates that were active against 2 pathogens were $W W_{4} P_{2}$ which was active against $S$. typhimurium and E. coli, and WRE ${ }_{10} \mathrm{P}_{2}$ showing inhibition of $P$. aeruginosa and S. pneumoniae. The remaining 5 isolates showed inhibition of only one pathogen. All of the tests were performed in triplicates and standard errors were calculated. Table 2 summarizes the zones of inhibition and antibacterial activities of rhizosphere bacterial isolates.

\subsubsection{Evaluation of antifungal activity}

When tested against fungal pathogens, isolate $W_{3} \mathrm{P}_{1}$ inhibited the growth of $A$. fumigatus as well as A. niger, whereas, isolate $\mathrm{WRE}_{10} \mathrm{P}_{2}$ was most effective against $A$. fumigatus. Both isolates showed inhibition against $A$. nidulans. The inhibition zones were visible and different interaction patterns were observed. Control plates showed considerable increased growth of the fungal cultures, however, rhizosphere bacterial isolates in test culture plates showed considerable inhibition of fungal mycelia (Fig. 3).

\subsection{Physicochemical analysis of bacteriocins}

\subsubsection{Effect of proteinase $K$ on bacteriocin activity}

Proteinase K-treated bacteriocins demonstrated a considerable reduction in antibacterial activities as compared to the results of controls in which bacteriocins without proteinase $\mathrm{K}$ treatment were added. Strain $\mathrm{WRE}_{4} \mathrm{P}_{2}$ exhibited partial inactivation against MRSA $(1.2 \pm 0.5 \mathrm{~mm})$ after treatment with proteinase $\mathrm{K}$ (Control value: $3 \pm 0.29 \mathrm{~mm}$ ). Furthermore, $W_{2} \mathrm{P}_{1}, W W_{3} \mathrm{P}_{1}, W W_{4} \mathrm{P}_{1}, W W_{11} \mathrm{P}_{1}, W W_{4} \mathrm{P}_{2}$, $W_{R E} P_{2}$, and $W R E_{10} P_{2}$ strains manifested complete inactivation in their antibacterial potential against various pathogenic strains, which confirms their proteinaceous characteristics (Table 3, Fig. 4).

\subsubsection{Effect of surfactants}

The effect of the surfactants SDS and EDTA on the activity of bacteriocins was determined against different pathogens and compared with controls by noting the zone of inhibition around the wells. The results in Table 4 clearly indicate that EDTA increased the antimicrobial activity of $W_{2} \mathrm{P}_{1}$ against $P$. aeruginosa, $K$. pneumonia and $E$. coli. $\mathrm{WRE}_{4} \mathrm{P}_{2}$ showed remarkable activity against $P$. aeruginosa and $E$. coli. WRE ${ }_{10} \mathrm{P}_{2}$ was active against $S$. pneumoniae. SDS showed a slight increase in the activity of bacteriocins of only two isolates, $W_{2} \mathrm{P}_{1}$ against $K$. pneumonia and $\mathrm{WRE}_{4} \mathrm{P}_{2}$, against $E$. coli (Table 4).

\subsubsection{Effect of temperature}

The present study found substantial stability of bacteriocins against bacterial pathogens at the temperature range of $20-80^{\circ} \mathrm{C}$. Against $P$. aeruginosa, maximum antimicrobial activity was shown by $W W_{2} P_{1}$ and $W_{R E} P_{2}$ at $80{ }^{\circ} \mathrm{C}$, and by $W W_{4} P_{1}$ and $W R E_{5} P_{2}$ at $20^{\circ}$ C. Bacteriocins from $W W_{2} P_{1}$, $W_{4} \mathrm{P}_{2}, W_{10} \mathrm{P}_{10}, \mathrm{WW}_{11} \mathrm{P}_{1}$ and $\mathrm{WRE}_{6} \mathrm{P}_{2}$, indicated highest antimicrobial activity at $20{ }^{\circ} \mathrm{C}$ against $K$. pneumonia, 


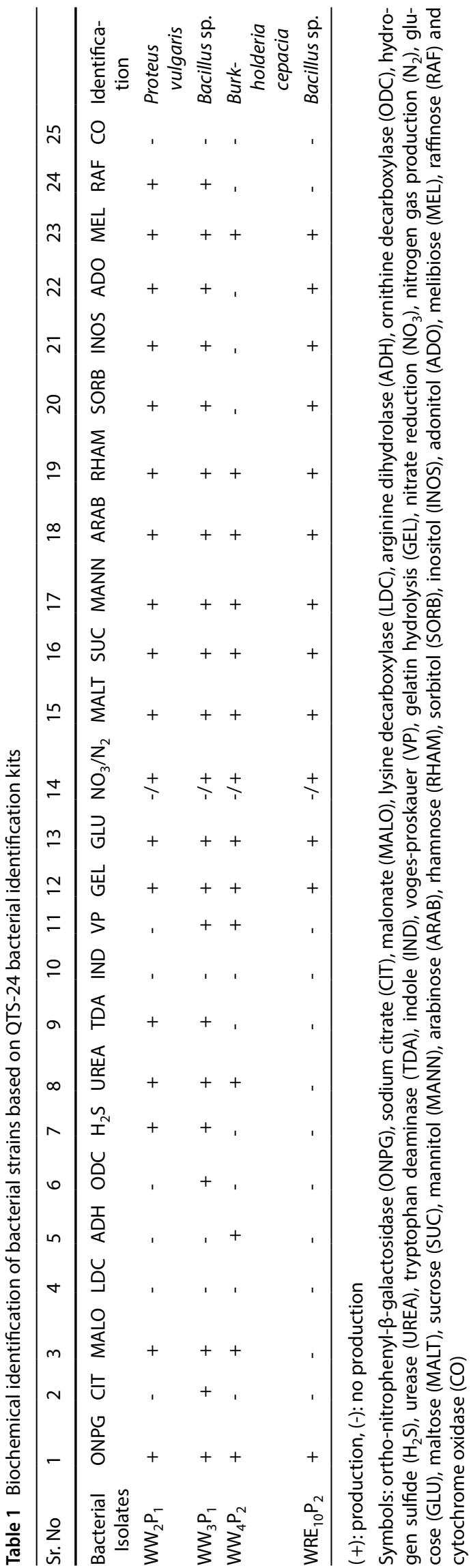

S. typhimurium, S. pneumoniae, P. aeruginosa and MRSA, respectively. In case of $E$. coli, the highest antimicrobial activity was shown by $W_{2} \mathrm{P}_{1}$ at 60 and $80^{\circ} \mathrm{C}$, by $W_{3} \mathrm{P}_{1}$ and $W_{W} \mathrm{P}_{2}$ at $20^{\circ} \mathrm{C}$ and by $\mathrm{WRE}_{4} \mathrm{P}_{2}$ at $60^{\circ} \mathrm{C}$ (Table 5).

\subsubsection{Effect of $\mathrm{pH}$}

The influence of $\mathrm{pH}$ ranging from 2 to 14 on the activity of purified bacteriocins against various pathogens was observed by calculating their zone of inhibition. Bacterial strains $W W_{2} P_{1}, W W_{4} P_{1}, W R E_{4} P_{2}$ and $W R E_{5} P_{2}$ showed maximum stability against $P$. aeruginosa at $\mathrm{pH} 10,14$, and 2 respectively. Against $E$. coli, maximum stability was observed by bacterial strains $W W_{2} P_{1}$ and $W W_{4} P_{2}$ at $p H 14$, by $W_{3} \mathrm{P}_{1}$ at $\mathrm{pH} 4$ and by $\mathrm{WRE}_{4} \mathrm{P}_{2}$ at $\mathrm{pH}$ 2. In case of MRSA, $W_{11} P_{1}, W R E_{4} P_{2}$ and $W R E_{6} P_{2}$ showed maximum stability at $\mathrm{pH} 4,12$ and 2 respectively. Bacteriocins from $W_{2} \mathrm{P}_{1}$ had high stability against $K$. pneumonia at both $\mathrm{pH} 10$ and 14 . The maximum stability of $\mathrm{WW}_{4} \mathrm{P}_{2}$ against $S$. typhimurium and $\mathrm{WRE}_{10} \mathrm{P}_{2}$ against $S$. pneumoniae and $P$. aeruginosa was at pH 2, 10 and 14, respectively (Table 6, Fig. 5).

\section{Discussion}

Appropriate alternatives to conventional antibiotics which are safer, cheaper, biodegradable and easily administered is the focus of much current research [22]. This study was aimed at isolating the bacterial strains which could synthesize both chitinase and bacteriocins, that could hinder fungal and bacterial growth, respectively. The antibacterial and antifungal potential of isolates was determined through agar well diffusion and dual plate culture assay, respectively. The isolates were screened for their antimicrobial activities against six validated bacterial and three fungal pathogens affecting humans.

Of the 41 phenotypically different bacterial isolates of wheat, 25 showed the production of bacteriocins. These 25 isolates were screened against six human bacterial pathogens by agar-well diffusion method. In total, 9 bacterial isolates of wheat showed considerable suppression of bacterial pathogens and further evaluated under treatment of different physicochemical parameters such as treatment with proteinase $\mathrm{K}$, temperature, $\mathrm{pH}$ and surfactants. Upon treatment with proteinase $\mathrm{K}$, significant reduction in antibacterial activities of wheat rhizobacteria was observed confirming the proteinaceous nature of bacteriocins. This reduction has been demonstrated by several bacteriocin producing bacteria previously where treatment with proteinase $\mathrm{K}$ has decreased their antibacterial potential [23, 24].

Parameters like the effect of temperature, $\mathrm{pH}$ and surfactants on the activity of bacteriocins against pathogens 
Table 2 Screening of purified bacteriocins for antibacterial activity

\begin{tabular}{|c|c|c|c|c|c|c|}
\hline \multirow[t]{2}{*}{ Bacterial strains } & \multicolumn{6}{|l|}{ Pathogens } \\
\hline & E. coli & K. pneumoniae & MRSA & P. aeruginosa & S. typhimurium & S.pneumoniae \\
\hline$W_{2} P_{1}$ & $2.33 \pm 0.29$ & $1.67 \pm 0.29$ & - & $3.17 \pm 0.29$ & - & - \\
\hline$W_{3} P_{1}$ & $2 \pm 0.5$ & - & - & - & - & - \\
\hline$W W_{4} P_{1}$ & - & - & - & 3.5 & - & - \\
\hline $\mathrm{WW}_{11} \mathrm{P}_{1}$ & - & - & $1.17 \pm 0.29$ & - & - & - \\
\hline$W_{4} P_{2}$ & $1.67 \pm 0.29$ & - & - & - & $1.67 \pm 0.29$ & - \\
\hline $\mathrm{WRE}_{4} \mathrm{P}_{2}$ & $2.83 \pm 0.29$ & - & $2 \pm 0.5$ & $3.17 \pm 0.29$ & - & - \\
\hline WRE $_{5} \mathrm{P}_{2}$ & - & - & - & 2.5 & - & - \\
\hline WRE $_{6} \mathrm{P}_{2}$ & - & - & 3.5 & - & - & - \\
\hline $\mathrm{WRE}_{10} \mathrm{P}_{2}$ & - & - & - & $2.17 \pm 0.29$ & - & $1.67 \pm 0.29$ \\
\hline
\end{tabular}

*Numbers in the table indicate zones in mm. MRSA: Methicillin-resistant Staphylococcus aureus, (-): no activity

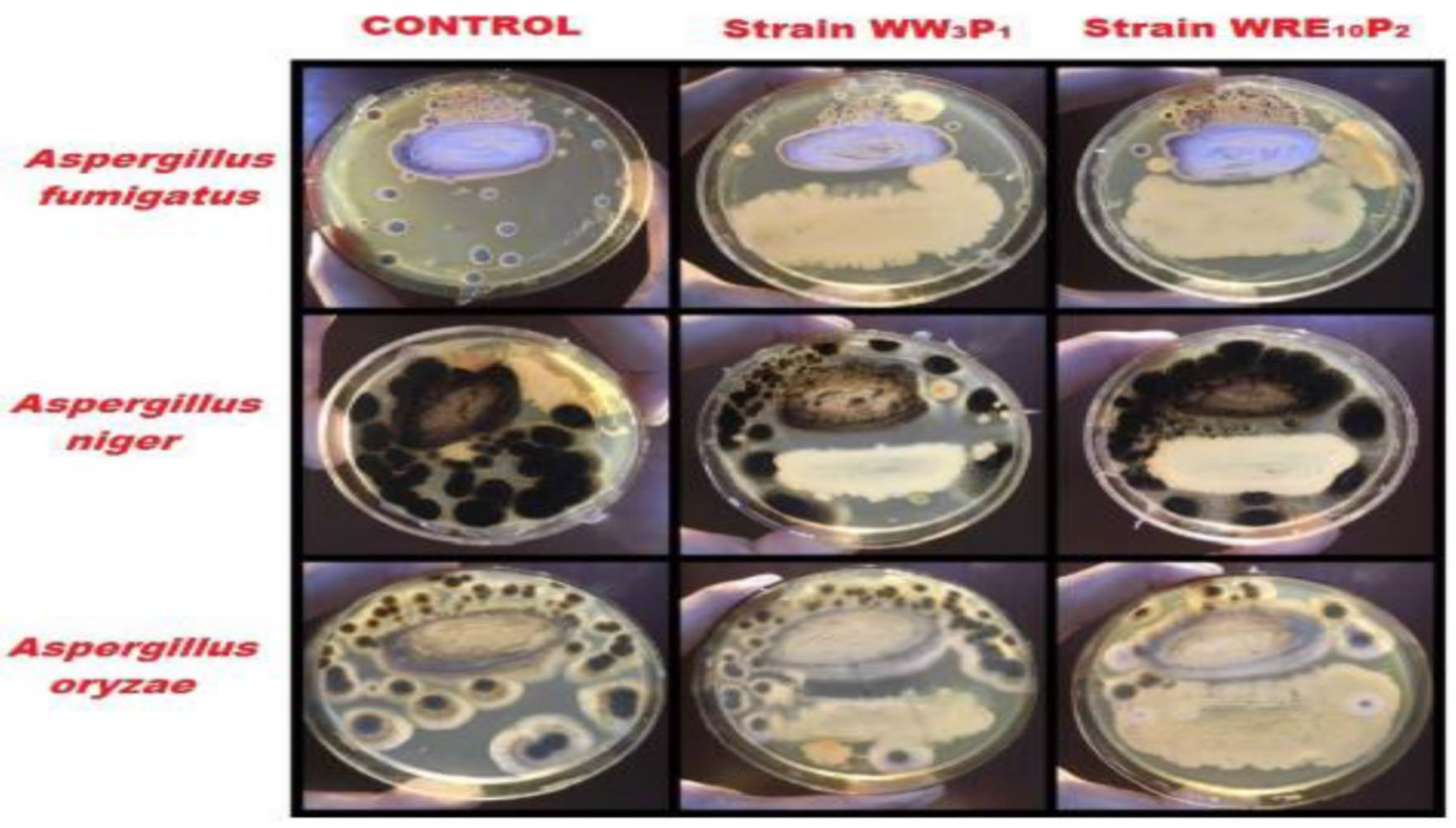

Fig. 3 Inhibitory action of isolates towards Aspergillus strains

were also demonstrated. Bacteriocin activity was greatly affected by changes in temperature and $\mathrm{pH}$, and the presence of surfactants $[8,25,26]$. These results are in accordance with previously reported literature where bacteriocins were shown to be influenced by these parameters. For example, bacteriocin ST712BZ had maximum production when incubated at $30^{\circ} \mathrm{C}$ instead of $37^{\circ} \mathrm{C}$ [3]. For the assessment of heat stability of purified bacteriocins, bacteriocins were subjected to different temperatures followed by the assay of their antibacterial potential. Bacteriocins from $W W_{3} P_{1}, W W_{4} P_{1}, W W_{11} P_{1}, W W_{4} P_{2}, W R E_{5} P_{2}, W R E_{6} P_{2}$ and $W R E_{10} P_{2}$ were active against different pathogens at $20{ }^{\circ} \mathrm{C}$. Whereas, bacteriocins from isolates $W_{2} \mathrm{P}_{1}$ and WRE ${ }_{4} \mathrm{P}_{2}$ were most stable at 60 and $80^{\circ} \mathrm{C}$ against different pathogens. Bacteriocin activity was greatly reduced above $80^{\circ} \mathrm{C}$.

Knowledge of the stability of bacteriocins resulting from $\mathrm{pH}$ alteration has been used for the preservation of various fermented foods [3]. Sharma et al. (2018) reported that bacteriocins named $\mathrm{LR}_{6}$ and $\mathrm{LD}_{3}$ were stable at $\mathrm{pH} 2$ to 6 [27]. $W_{2} \mathrm{P}_{1}, \mathrm{WW}_{4} \mathrm{P}_{1}, \mathrm{WRE}_{4} \mathrm{P}_{2}$ and $\mathrm{WRE}_{5} \mathrm{P}_{2}$ showed maximum stability at $\mathrm{pH} 10,14$, and 2 , respectively, and showed significant inhibition of $P$. aeruginosa. Against $E$. coli, maximum stability was observed by bacteriocins isolated from bacterial strains $W_{2} \mathrm{P}_{1}$ and $W W_{4} \mathrm{P}_{2}$ at $\mathrm{pH} 14$, by $\mathrm{WW}_{3} \mathrm{P}_{1}$ at $\mathrm{pH} 4$ and by $\mathrm{WRE}_{4} \mathrm{P}_{2}$ at $\mathrm{pH}$ 2. In case of MRSA, WW ${ }_{11} \mathrm{P}_{1}$, $\mathrm{WRE}_{4} \mathrm{P}_{2}$ and $W \mathrm{WR}_{6} \mathrm{P}_{2}$ bacteriocins showed maximum stability at $\mathrm{pH} 4,12$ and 2 , respectively. Bacteriocins from $W_{2} \mathrm{P}_{1}$ 
Table 3 Effect of proteinase K on bacteriocins activity

\begin{tabular}{llll}
\hline Bacterial strains & Pathogens & Control & $\begin{array}{l}\text { Enzyme } \\
\text { (Proteinase } \\
\text { K) }\end{array}$ \\
& $\mathrm{mm}$ & & \\
& & & \\
\hline $\mathrm{WW}_{2} \mathrm{P}_{1}$ & P. aeruginosa & $2.33 \pm 0.29$ & - \\
& K. pneumoniae & $1.67 \pm 0.29$ & - \\
& E. coli & $3.17 \pm 0.29$ & - \\
$\mathrm{WW}_{3} \mathrm{P}_{1}$ & E. coli & $2 \pm 0.5$ & - \\
$\mathrm{WW}_{4} \mathrm{P}_{1}$ & P. aeruginosa & 3.5 & - \\
$\mathrm{WW}_{11} \mathrm{P}_{1}$ & MRSA & $1.17 \pm 0.29$ & - \\
$\mathrm{WW}_{4} \mathrm{P}_{2}$ & S. typhimurium & $1.67 \pm 0.29$ & - \\
& E. coli & $1.67 \pm 0.29$ & - \\
$\mathrm{WRE}_{4} \mathrm{P}_{2}$ & P. aeruginosa & $3.17 \pm 0.29$ & - \\
& MRSA & $3 \pm 0.29$ & $1.2 \pm 0.5$ \\
& E. coli & $2.83 \pm 0.29$ & - \\
$\mathrm{WRE}_{5} \mathrm{P}_{2}$ & P. aeruginosa & $2.5 \pm 0.29$ & - \\
$\mathrm{WRE}_{6} \mathrm{P}_{2}$ & MRSA & $3.5 \pm 0.5$ & - \\
$\mathrm{WRE}_{10} \mathrm{P}_{2}$ & S. pneumoniae & $1.67 \pm 0.29$ & - \\
& P. aeruginosa & $2.17 \pm 0.29$ & - \\
\hline
\end{tabular}

(-): no activity had high stability against $K$. pneumoniae at both $\mathrm{pH} 10$ and 14. The maximum stability of $W_{4} \mathrm{P}_{2}$ against $S$. typhimurium and $\mathrm{WRE}_{10} \mathrm{P}_{2}$ against $S$. pneumoniae and $P$. aeruginosa was at $\mathrm{pH} 2,10$ and 14 respectively.

Deraz et al. [23] have reported the that treatment of bacteriocins with reagents like EDTA or SDS enhanced their inhibitory activity on account of proteins getting unfolded, which then directly influences their antimicrobial activity [23]. In this study, two of the most common detergents i.e., SDS and EDTA were used at certain specified concentrations to determine their effect against different pathogens. Results demonstrated that SDS caused decreased bacteriocin activity. However, EDTA treatment increased the bacteriocin activity of $W_{2} \mathrm{P}_{1}$ against $P$. aeruginosa, K. pneumoniae and $E$. coli, of $\mathrm{WRE}_{4} \mathrm{P}_{2}$ against $P$. aeruginos $a$ and $E$. coli and of $\mathrm{WRE}_{10} \mathrm{P}_{2}$ against $S$. pneumoniae.

Studies have shown that use of bacteriocins in food preservation is safe and possible [20]. Being cheaper and safer, they can also be used as an alternative to antibiotics and have the advantage of overcoming the problem of bacterial resistance to antibiotics, which is a growing problem [8]. More research is needed on ways to manipulate bacteriocins through genetic and metabolic engineering to enhance their potency.



Fig. 4 Effect of proteinase $\mathrm{K}$ on bacteriocins activity 
Table 4 Effect of surfactants on bacteriocins activity

\begin{tabular}{|c|c|c|c|c|}
\hline \multirow{3}{*}{$\begin{array}{l}\text { Bacterial } \\
\text { strains }\end{array}$} & \multirow[t]{3}{*}{ Pathogens } & \multirow[t]{3}{*}{ Control } & \multicolumn{2}{|l|}{ Detergents } \\
\hline & & & SDS & EDTA \\
\hline & & & $\mathrm{mm}$ & \\
\hline \multirow[t]{3}{*}{$W_{2} P_{1}$} & $\begin{array}{l}\text { P. aerugi- } \\
\text { nosa }\end{array}$ & $1.87 \pm 0.5$ & $1 \pm 0.5$ & $2 \pm 0.235$ \\
\hline & $\begin{array}{l}\text { K. pneumo- } \\
\text { nia }\end{array}$ & $1.5 \pm 0.763$ & $2 \pm 0.408$ & $3.5 \pm 0.288$ \\
\hline & E. coli & $2 \pm 0.408$ & $1.23 \pm 0.5$ & $2.5 \pm 1.040$ \\
\hline$W W_{3} P_{1}$ & E. coli & $2 \pm 0.5$ & - & $1.87 \pm 0.408$ \\
\hline$W_{4} P_{1}$ & $\begin{array}{l}\text { P. aerugi- } \\
\text { nosa }\end{array}$ & $3.5 \pm 0.408$ & - & $3 \pm 0.5$ \\
\hline$W_{11} P_{1}$ & MRSA & $2 \pm 0.408$ & $1 \pm 0.5$ & 1.5 \\
\hline \multirow[t]{2}{*}{$W W W_{4} P_{2}$} & $\begin{array}{l}\text { S. typhimu- } \\
\text { rium }\end{array}$ & $2.7 \pm 0.408$ & $2.1 \pm 0.5$ & $2.57 \pm 0.235$ \\
\hline & E. coli & $1.57 \pm 0.408$ & - & $1.57 \pm 0.5$ \\
\hline \multirow[t]{3}{*}{$W_{R E} P_{4}$} & $\begin{array}{l}\text { P. aerugi- } \\
\text { nosa }\end{array}$ & $2.4 \pm 0.408$ & $1.5 \pm 0.5$ & $2.5 \pm 0.763$ \\
\hline & $M R S A$ & $2.5 \pm 0.408$ & $1.87 \pm 0.763$ & 2.5 \\
\hline & E. coli & $1.5 \pm 0.763$ & $1.67 \pm 0.5$ & $2.7 \pm 0.5$ \\
\hline $\mathrm{WRE}_{5} \mathrm{P}_{2}$ & $\begin{array}{l}\text { P. aerugi- } \\
\text { nosa }\end{array}$ & $2 \pm 0.6236$ & - & $1.5 \pm 0.5$ \\
\hline $\mathrm{WRE}_{6} \mathrm{P}_{2}$ & MRSA & $2.5 \pm 0.408$ & - & $1.2 \pm 0.5$ \\
\hline \multirow[t]{2}{*}{$\mathrm{WRE}_{10} \mathrm{P}_{2}$} & $\begin{array}{l}\text { S. pneumo- } \\
\text { niae }\end{array}$ & $1.89 \pm 0.408$ & $1.5 \pm 0.5$ & $3 \pm 0.6236$ \\
\hline & $\begin{array}{c}\text { P. aerugi- } \\
\text { nosa }\end{array}$ & $2 \pm 0.288$ & $1 \pm 0.763$ & $1.5 \pm 0.5$ \\
\hline
\end{tabular}

(-): no activity
Chitinases produced by bacteria degrade the chitin which is an important ingredient of fungal cell wall and lead to fungal growth inhibition. Out of forty-one wheat bacterial isolates two Bacillus isolates showed significant fungal inhibition of Aspergillus species. Similar results were reported by Rao and coworkers [28].

$W W_{3} P_{1}$ and $W R E_{10} P_{2}$ bacterial isolates showed different inhibitory patterns towards selected Aspergillus spp. strains. According to this study, $W_{3} \mathrm{P}_{1}$ showed maximum activity against Aspergillus fumigatus followed by Aspergillus niger, whereas, $\mathrm{WW}_{3} \mathrm{P}_{1}$ showed good activity against Aspergillus fumigatus. Bacillus spp. were also tested against Aspergillus nodulans, where both exhibited a moderate inhibition of fungal growth. Similarly, a study reported that Bacillus solani inhibited the growth of different fungal plant pathogens, giving a promising outlook for the use of the genus Bacillus as bio-control agents against fungal plant pathogens [29].

A more convenient and natural alternative to antibiotics and antifungal drugs is possible. The promising results from our research are a step forward to the future application of bacteriocin and chitinase antimicrobials in medical and agricultural industry.
Table 5 Effect of temperature on bacteriocins activity

\begin{tabular}{|c|c|c|c|c|c|c|}
\hline \multirow[t]{3}{*}{ Bacterial strains } & \multirow[t]{3}{*}{ Pathogens } & \multicolumn{5}{|l|}{ Temperature } \\
\hline & & $20^{\circ} \mathrm{C}$ & $40^{\circ} \mathrm{C}$ & $60^{\circ} \mathrm{C}$ & $80^{\circ} \mathrm{C}$ & $100^{\circ} \mathrm{C}$ \\
\hline & & $\mathrm{mm}$ & & & & \\
\hline \multirow[t]{3}{*}{$W W_{2} P_{1}$} & P. aeruginosa & $2 \pm 0.235$ & $1.5 \pm 0.5$ & $1.87 \pm 0.408$ & $5 \pm 0.288$ & $1 \pm 0.623$ \\
\hline & K. pneumoniae & $2.5 \pm 0.408$ & $1.92 \pm 0.763$ & 1.5 & $1.5 \pm 0.5$ & - \\
\hline & E. coli & $2 \pm 0.235$ & $2 \pm 0.5$ & $2.5 \pm 0.623$ & $2.5 \pm 0.408$ & - \\
\hline$W W_{3} P_{1}$ & E. coli & $2 \pm 0.5$ & $1.5 \pm 0.763$ & $1.5 \pm 0.408$ & - & - \\
\hline$W W W_{4} P_{1}$ & P. aeruginosa & $3.5 \pm 0.288$ & $2.5 \pm 0.235$ & $2 \pm 0.408$ & $1.23 \pm 0.763$ & - \\
\hline $\mathrm{WW}_{11} \mathrm{P}_{1}$ & MRSA & $3.2 \pm 0.5$ & $2 \pm 0.408$ & $1.5 \pm 0.288$ & $1.34 \pm 0.5$ & - \\
\hline \multirow[t]{2}{*}{$W_{4} P_{2}$} & S. typhimurium & $3 \pm 0.288$ & $2.34 \pm 0.763$ & 2.5 & $1.75 \pm 0.5$ & - \\
\hline & E. coli & $2.13 \pm 0.288$ & $2 \pm 0.408$ & $1.87 \pm 0.5$ & $1.87 \pm 0.5$ & - \\
\hline \multirow[t]{3}{*}{$\mathrm{WRE}_{4} \mathrm{P}_{2}$} & P. aeruginosa & $2 \pm 0.235$ & $1.5 \pm 0.408$ & $3 \pm 0.5$ & $4 \pm 0.408$ & $1 \pm 0.5$ \\
\hline & MRSA & $1.5 \pm 0.235$ & $2 \pm 0.623$ & $3.5 \pm 0.408$ & $3 \pm 0.288$ & - \\
\hline & E. coli & $2 \pm 0.408$ & $1.97 \pm 0.5$ & $4 \pm 0.235$ & $2.5 \pm 0.40$ & - \\
\hline $\mathrm{WRE}_{5} \mathrm{P}_{2}$ & P. aeruginosa & $2.5 \pm 0.5$ & $1.5 \pm 0.235$ & $1.13 \pm 0.235$ & - & - \\
\hline $\mathrm{WRE}_{6} \mathrm{P}_{2}$ & MRSA & $2.5 \pm 0.288$ & $2 \pm 0.408$ & $1 \pm 0.5$ & - & - \\
\hline \multirow[t]{2}{*}{$\mathrm{WRE}_{10} \mathrm{P}_{2}$} & S. pneumoniae & $2.87 \pm 0.288$ & $2 \pm 0.763$ & $1.87 \pm 0.408$ & $1.5 \pm 0.5$ & - \\
\hline & P. aeruginosa & 3 & $2.5 \pm 0.763$ & $2 \pm 0.408$ & $1.5 \pm 0.40$ & - \\
\hline
\end{tabular}

(-): no activity 
Table 6 Effect of $\mathrm{pH}$ on bacteriocins activity

\begin{tabular}{|c|c|c|c|c|c|c|c|c|}
\hline \multirow{3}{*}{$\begin{array}{l}\text { Bacterial } \\
\text { strains }\end{array}$} & \multirow[t]{3}{*}{ Pathogens } & \multicolumn{7}{|l|}{$\mathrm{pH}$} \\
\hline & & 2 & 4 & 6 & 8 & 10 & 12 & 14 \\
\hline & & $\mathrm{mm}$ & & & & & & \\
\hline \multirow[t]{3}{*}{$W W_{2} P_{1}$} & P. aeruginosa & $2.166 \pm 0.288$ & $1.5 \pm 0.5$ & $2 \pm 0.5$ & $1.833 \pm 0.288$ & $2.5 \pm 0.5$ & $2.166 \pm 0.763$ & $2 \pm 0.5$ \\
\hline & K.pneumonia & 2 & $1.66 \pm 0.288$ & $2 \pm 0.5$ & $1.833 \pm 0.763$ & $2.5 \pm 0.408$ & $1.833 \pm 0.6236$ & $2.5 \pm 0.408$ \\
\hline & E. coli & $\mathrm{Nd}$ & $1.5 \pm 0.408$ & $1.833 \pm 0.235$ & $2 \pm 0.408$ & $2.5 \pm 0.408$ & $3 \pm 0.408$ & $3.33 \pm 0.6236$ \\
\hline$W W_{3} P_{1}$ & E. coli & $3.66 \pm 0.7637$ & $3.833 \pm 0.763$ & $2.833 \pm 0.763$ & $2 \pm 0.5$ & $1.5 \pm 0.5$ & $1.833 \pm 1.040$ & $3.5 \pm 0.5$ \\
\hline$W W_{4} P_{1}$ & P. aeruginosa & $2 \pm 0.5$ & $3.5 \pm 0.5$ & $2.5 \pm 0.763$ & $6 \pm 0.5$ & $7 \pm 0.5$ & $7.166 \pm 0.7637$ & $7.5 \pm 0.5$ \\
\hline$W W_{11} P_{1}$ & MRSA & $2.166 \pm 0.763$ & $8 \pm 0.55$ & $2 \pm 0.763$ & $2.5 \pm 0.5$ & $3 \pm 0.408$ & $2.5 \pm 0.5$ & $4 \pm 0.763$ \\
\hline \multirow[t]{2}{*}{$W W_{4} P_{2}$} & S. typhimurium & $6 \pm 0.5$ & $2 \pm 0.763$ & $3.833 \pm 0.763$ & $1.833 \pm 0.763$ & $4.5 \pm 0.5$ & $3.88 \pm 0.763$ & $2 \pm 0.5$ \\
\hline & E.coli & $5 \pm 0.5$ & $2.166 \pm 0.288$ & $2.5 \pm 0.5$ & $2.5 \pm 0.763$ & $3.5 \pm 0.5$ & $4.5 \pm 0.5$ & $6.5 \pm 0.5$ \\
\hline \multirow[t]{3}{*}{$\mathrm{WRE}_{4} \mathrm{P}_{2}$} & P. aeruginosa & $2.5 \pm 0.5$ & $1.833 \pm 0.267$ & $1.5 \pm 0.5$ & $1.5 \pm 0.5$ & $2.5 \pm 0.408$ & $1.833 \pm 0.40$ & $4 \pm 0.1 .833$ \\
\hline & MRSA & $1.833 \pm 0.6236$ & $2 \pm 0.5$ & $2.5 \pm 0.288$ & $1.5 \pm 0.763$ & $2.5 \pm 0.408$ & 3 & $2.5 \pm 0.5$ \\
\hline & E. coli & $4 \pm 0.5$ & $2.5 \pm 0.763$ & $1.5 \pm 0.5$ & $1.5 \pm 0.5$ & 2.5 & $2.5 \pm 0.5$ & $3.5 \pm 0.822$ \\
\hline $\mathrm{WRE}_{5} \mathrm{P}_{2}$ & P. aeruginosa & $11 \pm 0.5$ & $7.5 \pm 0.5$ & $5.25 \pm 0.763$ & $7 \pm 0.5$ & $7.5 \pm 0.5$ & $8 \pm 0.763$ & $9 \pm 0.823$ \\
\hline $\mathrm{WRE}_{6} \mathrm{P}_{2}$ & MRSA & $6.5 \pm 0.763$ & $4 \pm 0.5$ & 3.5 & $3.5 \pm 0.5$ & $3.5 \pm 0.833$ & $4 \pm 0.5$ & $6 \pm 0.763$ \\
\hline \multirow[t]{2}{*}{$\mathrm{WRE}_{10} \mathrm{P}_{2}$} & S. pneumoniae & $1.5 \pm 0.5$ & $1.5 \pm 0.267$ & $4 \pm 0.763$ & $5 \pm 0.408$ & $6 \pm 0.5$ & $2 \pm 0.267$ & 3 \\
\hline & P. aeruginosa & $1 \pm 0.5$ & $2 \pm 0.288$ & $2.5 \pm 0.267$ & 2.5 & $3 \pm 0.5$ & 3 & $4.67 \pm 0.5$ \\
\hline
\end{tabular}

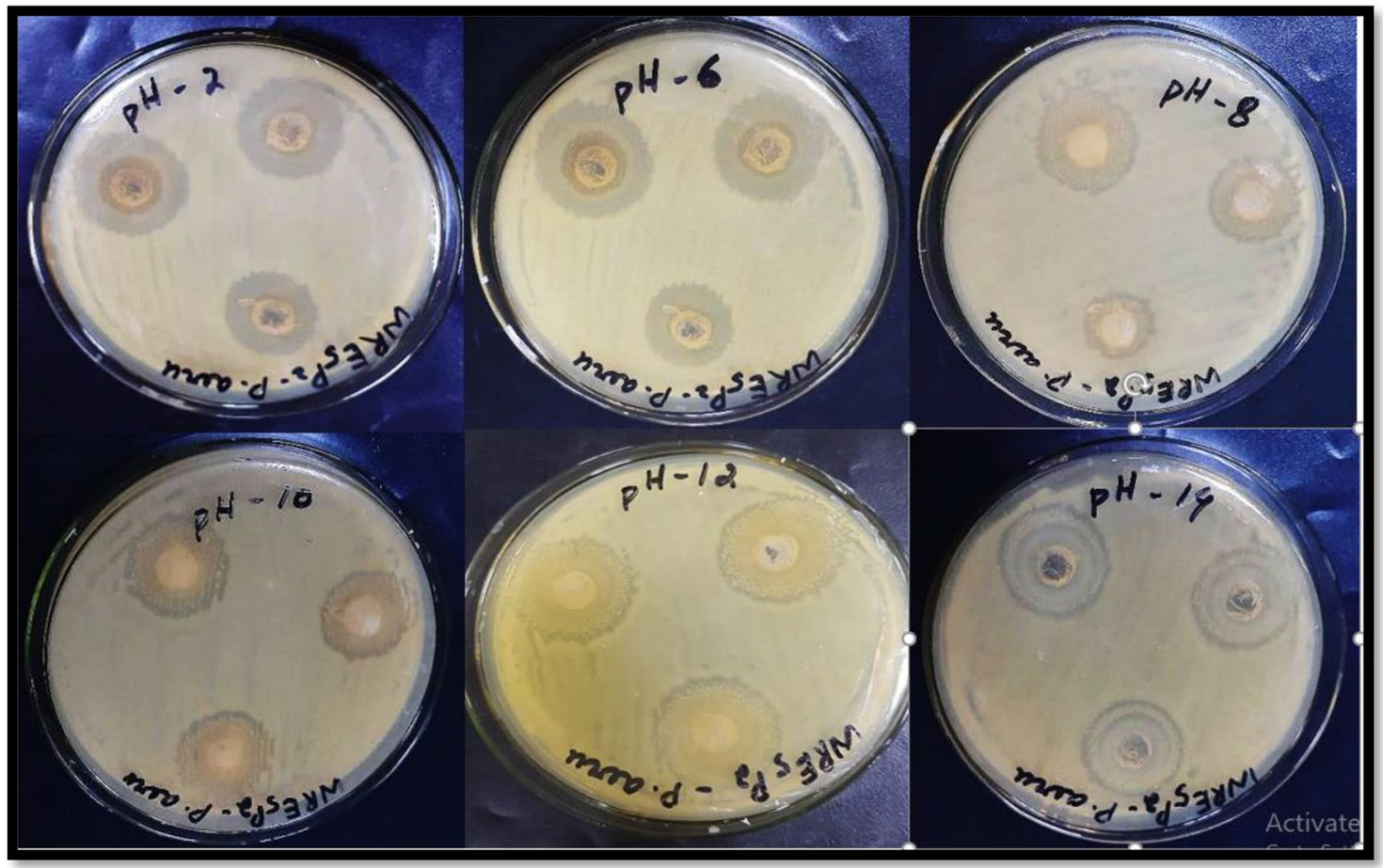

Fig. 5 Effect of different pH on bacteriocin activity against specific pathogens

Acknowledgements We wish to thank Mr. Waqas Saleem and Mr. Zunair Akmal for their technical assistance in this study. We are also grateful for the support of the Department of Microbiology, PKLI \& RC.
Author contributions All authors contributed to the conception and design of this study. Material preparation, data collection and analysis were performed by [Muhammad Yasir], [Hafza Khalid] and [Basit 
Zeshan]. The first draft of the manuscript was written by [Nur Hardy A. Daud] and [Izzah Shahid] and all authors commented on previous versions of the manuscript. Revision of manuscript and English proofreading were undertaken by [Basit Zeshan]. All authors read and approved the final manuscript.

Funding This research did not receive any specific grant from funding agencies in the public, commercial, or not-for-profit sectors.

Data availability We are willing to share our data upon request. Please contact Dr. Basit Zeshan (email: dr.basitzeshan@ucp.edu.pk) for this purpose.

\section{Declarations}

Conflict of interest The authors declare that they have no conflict of interest.

Ethical approval An approval from institution review board was obtained before starting the research work.

Consent to participate All authors have participated equally in the current research work.

Consent for publication All authors have read the guidelines related to the publication and are agree to publish this research work in SN Applied Sciences.

Open Access This article is licensed under a Creative Commons Attribution 4.0 International License, which permits use, sharing, adaptation, distribution and reproduction in any medium or format, as long as you give appropriate credit to the original author(s) and the source, provide a link to the Creative Commons licence, and indicate if changes were made. The images or other third party material in this article are included in the article's Creative Commons licence, unless indicated otherwise in a credit line to the material. If material is not included in the article's Creative Commons licence and your intended use is not permitted by statutory regulation or exceeds the permitted use, you will need to obtain permission directly from the copyright holder. To view a copy of this licence, visit http://creativecommons.org/licenses/by/4.0/.

\section{References}

1. Baindara P, Mandal SM, Chawla N, Singh PK, Pinnaka AK, Korpole $S$ (2013) Characterization of two antimicrobial peptides produced by a halotolerant Bacillus subtilis strain SK. DU. 4 isolated from a rhizosphere soil sample. AMB Express 3(1):1-11

2. Hwanhlem N, Chobert J-M, Aran H (2014) Bacteriocin-producing lactic acid bacteria isolated from mangrove forests in southern Thailand as potential bio-control agents in food: isolation, screening and optimization. Food Control 41:202-211

3. Elayaraja S, Annamalai N, Mayavu P, Balasubramanian T (2014) Production, purification and characterization of bacteriocin from Lactobacillus murinus AU06 and its broad antibacterial spectrum. Asian Pac J Trop Biomed 4:S305-S311

4. Cotter PD, Hill C, Ross RP (2005) Bacteriocins: developing innate immunity for food. Nat Rev Microbiol 3(10):777-788
5. Yanti Y, Hamid H, Habazar $\mathrm{T}$ (2020) The ability of indigenous Bacillus spp. consortia to control the anthracnose disease (Colletrotricum capsici) and increase the growth of chili plants. Biodiversitas J Biol Divers 21:179-186

6. Tariq F, Ahmed N, Afzal M, Khan MAU, Zeshan B (2020) Synthesis, characterization and antimicrobial activity of bacillus subtilisderived silver nanoparticles against multidrug-resistant bacteria. Jundishapur J Microbiol. https://doi.org/10.5812/jjm.91934

7. Itoh T, Kimoto H (2019) Bacterial chitinase system as a model of chitin biodegradation. In: Targeting Chitin-containing Organisms, Springer, Newyork

8. Bemena LD, Mohamed LA, Fernandes AM, Lee BH (2014) Applications of bacteriocins in food, livestock health and medicine. Int J Curr Microbiol App Sci 3(12):924-949

9. Oyeleye A, Normi YM (2018) Chitinase: diversity, limitations, and trends in engineering for suitable applications. Biosci Rep. https://doi.org/10.1042/BSR20180323

10. McCormick A, Loeffler J, Ebel F (2010) Aspergillus fumigatus: contours of an opportunistic human pathogen. Cell Microbiol 12(11):1535-1543

11. Kumar M, Brar A, Yadav M, Chawade A, Vivekanand V, Pareek $\mathrm{N}$ (2018) Chitinases_-potential candidates for enhanced plant resistance towards fungal pathogens. Agriculture 8(7):88

12. Shafi J, Tian H, Ji M (2017) Bacillus species as versatile weapons for plant pathogens: a review. Biotechnol Biotechnol Equip 31(3):446-459

13. Kumar S, Kaushik N, Edrada-Ebel R, Ebel R, Proksch P (2011) Isolation, characterization, and bioactivity of endophytic fungi of Tylophora indica. World J Microbiol Biotechnol 27(3):571-577

14. Rodriguez-Kabana R, Godoy G, Morgan-Jones G, Shelby R (1983) The determination of soil chitinase activity: conditions for assay and ecological studies. Plant Soil 75(1):95-106

15. Kang J, Lee $M(2005)$ Characterization of a bacteriocin produced by Enterococcus faecium GM-1 isolated from an infant. J Appl Microbiol 98(5):1169-1176

16. Ahmed N, Ali Z, Riaz M, Zeshan B, Wattoo Jl, Aslam MN (2020) Evaluation of antibiotic resistance and virulence genes among clinical isolates of pseudomonas aeruginosa from cancer patients. Asian Pacific journal of cancer prevention : APJCP 21(5):1333-1338. https://doi.org/10.31557/apjcp.2020.21.5. 1333

17. Ahmed N, Zeshan B, Naveed M, Afzal M, Mohamed M (2019) Antibiotic resistance profile in relation to virulence genes fimH, hlyA and usp of uropathogenic E. coli isolates in Lahore Pakistan. Tropical Biomed 36(2):559-568

18. Parveen S, Saqib S, Ahmed A, Shahzad A, Ahmed N (2020) Prevalence of MRSA colonization among healthcare-workers and effectiveness of decolonization regimen in ICU of a tertiary care hospital, Lahore Pakistan. Adv Life Sci 8(1):38-41

19. Pingitore EV, Salvucci E, Sesma F, Nader-Macias M (2007) Different strategies for purification of antimicrobial peptides from lactic acid bacteria (LAB). Commun Current Res Educational Topics Trends in Appl Microbiol 1:557-568

20. Saad MA, Abdelsamei HM, Ibrahim E, Abdou AM, El Sohaimy SA (2015) Effect of $\mathrm{pH}$, heat treatments and proteinase $\mathrm{K}$ enzyme on the activity of Lactobacillus acidophilus bacteriocin. Benha Veterinary Med J 28(1):210-215

21. Mandal V, Sen SK, Mandal NC (2008) Optimized culture conditions for bacteriocin production by Pediococcus acidilactici LAB 5 and its characterization. NISCAIR Online Periodicals Repository. http://nopr.niscair.res.in/handle/123456789/1481

22. Javed F, Ali Z, lqbal S, Ahmed N, Farooq Z, Masood F, Nawaz $M$ (2020) Production of synbiotic product containing galactooligosaccharides and saccharomyces boulardii and evaluation of its in-vitro bifidogenic effect. J Microbiol Biotechnol Food Sci 2020:197-200 
23. Deraz SF, Karlsson EN, Hedström M, Andersson MM, Mattiasson B (2005) Purification and characterisation of acidocin D20079, a bacteriocin produced by Lactobacillus acidophilus DSM 20079. J Biotechnol 117(4):343-354

24. Hernandez D, Cardell E, Zarate V (2005) Antimicrobial activity of lactic acid bacteria isolated from Tenerife cheese: initial characterization of plantaricin TF711, a bacteriocin-like substance produced by Lactobacillus plantarum TF711. J Appl Microbiol 99(1):77-84

25. Galvez A, López RL, Abriouel H, Valdivia E, Omar NB (2008) Application of bacteriocins in the control of foodborne pathogenic and spoilage bacteria. Crit Rev Biotechnol 28(2):125-152

26. Yang S-C, Lin C-H, Sung CT, Fang J-Y (2014) Antibacterial activities of bacteriocins: application in foods and pharmaceuticals. Front Microbiol 5:241
27. Sharma G, Dang S, Gupta S, Gabrani R (2018) Antibacterial activity, cytotoxicity, and the mechanism of action of bacteriocin from Bacillus subtilis GAS101. Med Princ Pract 27(2):186-192

28. Prakash Rao A, Agbo B, Udoekong N, Etuk H (2017) Evaluation of antagonistic potential of soil bacteria against plant pathogenic fungus: Aspergillus niger. J Adv Microbiol 3:1-7. https://doi.org/ 10.9734/JAMB/2017/33320

29. Swamy M (2018) Bioefficacy of Bacillus subtilis against Aspergillus flavus, the cause of aflatoxin contamination in chilli. Int J Chem Sci 6:2050-2053

Publisher's Note Springer Nature remains neutral with regard to jurisdictional claims in published maps and institutional affiliations. 